\section{Plant Density Effects on Single-head Broccoli Production}

\author{
Lewis W. Jett ${ }^{1}$, Ronald D. Morse ${ }^{2}$, and Charles R. O'Dell ${ }^{3}$ \\ Department of Horticulture, Virginia Polytechnic Institute and State University, \\ Blacksburg, VA 24061-0327
}

Additional index words. Brassica oleracea, density, floret yield

\begin{abstract}
There is a strong consumer demand for single-head broccoli (Brassica oleracea L. var. italica) that yields more florets per unit weight than bunching broccoli. Two spatial arrangements (single vs. twin row) and five plant densities (10.8, 7.2, 5.4, 4.3, and 3.6 plants $/ \mathbf{m}^{2}$ ) were examined for single-head broccoli production. Spatial arrangement had no significant effect on any measured attribute, although the twin-row arrangement resulted in less plant damage with each harvest. For exclusive production of quality, singlehead broccoli with high yields of marketable florets, 3.6 plants $/ \mathrm{m}^{2}$ (46-cm within-row spacing) should be used.
\end{abstract}

Per capita consumption of broccoli has increased $330 \%$ since 1975 (Hamm, 1988). As a result, fresh-market broccoli hectarage has increased by $\approx 10 \%$ annually since the early 1970s (Karst, 1990). Production acreage has expanded to include nontraditional broccoli producing areas, where broccoli is viewed as an alternative to traditional agronomic crops (Hamm, 1992).

Virginia is one of several southeastern states that has promoted fresh-market broccoli as an alternative cash crop after researchers successfully identified an open-market window for fall bunching broccoli (Sterrett et al., 1990). Virginia has a suitable climate for fall broccoli production and is adjacent to large population centers, resulting in lower transportation costs for providing high-quality fresh broccoli to consumers (Borchers, 1979).

In Virginia, the initial effort was to duplicate production, postharvest, and marketing practices used successfully for California bunching broccoli production. In this system, several small heads are bunched together to make a single marketable unit. Because high plant densities are required for profitable production of bunching broccoli, direct seeding normally is practiced to minimize plant establishment costs. In hot, humid climates, such as those in Virginia, producing fall bunching broccoli requires seeding during stressful summer climatic and edaphic conditions, which may reduce seedling emergence (Elso et al., 1992; Jett and Welbaum, 1992). Because many broccoli growers are part-time vegetable producers, full effort is not given to proper seedbed preparation, precision seeding techniques,

\footnotetext{
Received for publication 15 Apr. 1994. Accepted for publication 4 Aug. 1994. Mention of a proprietary product does not imply its approval to the exclusion of other products that may also be suitable. The cost of publishing this paper was defrayed in part by the payment of page charges. Under postal regulations, this paper therefore must be hereby marked advertisement solely to indicate this fact. ${ }^{1}$ Graduate Assistant.

${ }^{2}$ Associate Professor.

${ }^{3}$ Extension Specialist, Vegetable Crops.
}

mist irrigation of the seedbed, and over seeding and thinning are needed to achieve a desired plant stand. The combined effects of high soil temperatures, soil crusting, and poor cultural management practices have resulted in poor plant stand establishment and low broccoli yields for direct-seeded, fall broccoli crops in Virginia (Sterrett et al., 1990). technic Institute and State Univ., Blacksburg, conducted a survey of Virginia's master gardeners, who use many horticultural products, to determine consumer attitudes and preferences toward Virginia-grown broccoli. The survey respondents preferred $(>90 \%)$ largehead broccoli that contains more florets and less stalk per unit weight, which in this paper is termed "single-head broccoli" to describe a single head that is equivalent in size to a bunch of broccoli (Relf et al., 1990). Because broccoli stalks are discarded in most homes and restaurants, commercial sales of packaged broccoli florets is increasing rapidly. In the near future, broccoli florets sales are projected to equal and perhaps exceed the standard pack (bunching broccoli) in volume (Coon, 1991; Karst, 1993; Klassen, 1993).

Producing single-head broccoli would require fewer plants per unit area and, thus, transplants could be used for field establishment, alleviating the problems of poor stand establishment. Broccoli production in Virginia and other southeastern states is located in areas with large commercial hectarage of transplanted row crops. Thus, equipment and grower knowledge are available for production of high-quality transplants. Also, most labor required for fresh-market broccoli production is devoted to harvesting (O'Dell et al., 1993). Because of a lower plant population, singlehead broccoli likely would require fewer labor hours to harvest compared to high-density, bunching broccoli. Bacterial soft rot [Pseudomonas marginalis pv. marginalis (Brown) Stevens] often is a serious pathological problem, reducing broccoli yields in the southeastern United States (Canaday, 1992). Incidence of bacterial soft rot could possibly be reduced in the low-density, single-head
In 1988, horticulturists at Virginia Poly- fields compared to the high-density, bunching broccoli production systems.

Much of the prior research investigating plant density of broccoli has focused on determining the greatest population density that produces marketable head sizes for either processing or fresh-market bunching broccoli (Cutcliffe, 1971, 1975; Chung, 1982; Palevitch, 1970; Zink and Akana, 1951). Westcott and Callan (1990) investigated the effect of plant population density on head weight and area yield of broccoli. They showed that modeling can predict a plant density that, based on knowing head weights for widely spaced plants at that site, achieves a specified head weight for any geographical region. The objective of this model was to achieve the highest plant density of broccoli that ensures a marketable head size for bunching broccoli production. This model does not take into account the compensational ability of individual broccoli plants to effectively use the ground area at each plant density. Producing single-head broccoli is based on exploiting the compensational ability of the individual broccoli plant to determine the plant population that optimizes floret yield, the consumer-preferred component of broccoli.

Given the potential production advantages and the strong consumer interest in singlehead broccoli, the objectives of this research were to determine the feasibility of producing single-head broccoli and the optimal plant arrangement and spacing to maximize yield.

\section{Materials and Methods}

Experiments were conducted in 1990 and 1991 at the Virginia Tech Horticultural Research Farm, Christiansburg. Because 'Brigadier' (Petoseed Co., Saticoy, Calif.) produced medium to large heads in previous cultivar observation studies, it was selected for this experiment (C.R.O., unpublished). Uniform, 4- to 5-week-old, bare-rooted broccoli plants were hand-transplanted on 10 and 20 Aug. in 1990 and 1991, respectively. The soil, a Groseclose silt loam ( $\mathrm{pH}$ 6.2), was fertilized with (in kg.ha ${ }^{-1}$ ) $111 \mathrm{~N}-22 \mathrm{P}-47 \mathrm{~K}$ before transplanting, liquid $9 \mathrm{~N}-19 \mathrm{P}-12 \mathrm{~K}$ at 0.24 liter/ plant at transplanting, and $55.5 \mathrm{~N}-22 \mathrm{P}-47 \mathrm{~K} 7$ weeks after transplanting to coincide with floret initiation (Kowalenko and Hall, 1987). Foliar tissue samples were taken at the time of floret initiation for macro and micronutrient analysis. For broadleaf weed control, $\alpha, \alpha, \alpha-$ trifluor-2, 6-dinitro- $N, N$-dipropyl- $p$-toluidine (trifluralin) $(0.6 \mathrm{~kg}$ a.i/ha) was double-diskincorporated into the soil before transplanting. Supplemental overhead irrigation was used to deliver $\geq 25 \mathrm{~mm}$ of water per week.

To determine the optimal spatial arrangement for single-head broccoli production, plants were arranged in either single rows 61 $\mathrm{cm}$ apart, resulting in a more equidistant or square plant arrangement, or twin rows $(30 \mathrm{~cm}$ apart and $122 \mathrm{~cm}$ center to center), resulting in a more rectangular planting arrangement. In 1990, four within-row spacings (WRS) were examined: $15,30,38$, and $46 \mathrm{~cm}$, resulting in $10.8,5.4,4.3$, and 3.6 plants $/ \mathrm{m}^{2}$, respectively. 
The following year, five WRS were examined: $15,23,30,38$, and $46 \mathrm{~cm}$, resulting in $10.8,7.2,5.4,4.3$, and 3.6 plants $/ \mathrm{m}^{2}$ or 108,000 , $72,000,54,000,43,000$, and 36,000 plants/ha, respectively. For bunching broccoli production in Virginia and the southeastern United States, 10.8 plants $/ \mathrm{m}^{2}$ is optimal and is achieved by adhering to production practices such as seeding broccoli at double the final spacing and thinning to a desired stand (O'Dell, 1990). Traditional cultural practices for disease and insect control for broccoli production in Virginia were followed (O'Dell et al., 1993).

The design was a randomized complete block with three replications. Each plot was $4.6 \times 6.1 \mathrm{~m}$, and 20 plants per plot were harvested from the interior two rows. Harvesting was performed on alternate days starting the third week of Sept. 1990 or the first week of Oct. 1991, respectively.

United States grade standards for bunching broccoli state, "a single stalk may be considered equivalent to a bunch if it is approximately as large as other bunches in the lot" (U.S. Dept. of Agriculture, 1943). Because this definition is vague, preliminary studies were conducted to determine the head diameter that corresponded with the weight of a bunch of broccoli $(\approx 560 \mathrm{~g})$. Based on this study, broccoli that attained a head diameter of $\geq 20 \mathrm{~cm}$ was categorized as single-head broccoli. All broccoli heads were allowed to reach this target diameter, cut to $19 \mathrm{~cm}$ length, and trimmed of peripheral leaves at each harvest. If the heads were determined to be potentially unmarketable (i.e., too loose) before the next harvest, they were harvested and categorized as bunching broccoli. All harvested broccoli heads were evaluated subjectively for quality based on a scale from 1 (poor quality; unmarketable) to 5 (excellent quality). A harvest index was calculated as (total marketable head yield)/(total marketable head yield + waste) (Chung, 1982). Each year, floret yield was determined by randomly harvesting and weighing four replications of 10 to 14 bunches or single heads. The entire single head or bunch was weighed immediately after harvest, followed by separation and weighing the apical $\approx 9 \mathrm{~cm}$ of the head containing the florets. The remaining $\approx 10 \mathrm{~cm}$ of stalk was discarded. The floret percentage (total fresh weight/head or bunch) was multiplied by the fresh-market yield at each density to approximate area floret yield.

\section{Results and Discussion}

Palevitch (1970) noted that increasing plant population densities of processing broccoli from 4 plants $/ \mathrm{m}^{2}$ to 10 to 11 plants $/ \mathrm{m}^{2}$ increased yield, especially through using spacings approaching equidistant arrangements. In both years of our study, plant spatial arrangement had no significant effect on any measured variable. Therefore, all data are expressed with regard to spacing or plant density. Perhaps plant density was too low to be affected by arrangement approaching equidistance or the extent of limiting factors was too low to affect individual plant characteris- tics over the plant density range studied. Despite the lack of spatial difference, the twin row arrangement, because of a greater spacing between the twin rows, produced less plant damage (i.e., leaf and stem breakage) with each harvest.

Leaf macronutrients and micronutrients concentrations were in the sufficient range, and for each nutrient, there were no significant differences among spatial arrangement or plant density (data not shown). Maintaining high fertility levels across all treatments minimized the chance that nutrient deficiencies might occur and limit single-head broccoli yield at the higher plant densities. Westcott and Callan (1990) also showed no $\mathrm{N}$ rate $\times$ plant density interaction for broccoli.

Spacing effects. Yields at 46-cm WRS (3.6 plants $/ \mathrm{m}^{2}$ ) were the highest both years for exclusive production of high-quality, singlehead broccoli, although the $38-\mathrm{cm}$ spacing yielded equally well in 1990 (Table 1). There was no significant difference in quality among the WRS plant densities studied (data not shown).

In 1990 and 1991, head diameter, plant weight, and head weight increased as plant density decreased from 10.8 to 3.6 plants $/ \mathrm{m}^{2}$ (Table 2). Head weight increased by $232 \%$ in
1990 and $258 \%$ in 1991 as plant density decreased from 10.8 to 3.6 plants $/ \mathrm{m}^{2}$. However, as plant density decreased, total marketable crop yield (tonnes per hectare) decreased by $22 \%$ in 1990 and $12 \%$ in 1991 (Table 1). Thus, reducing plant populations by two-thirds for single-head broccoli production resulted in significant plant yield compensation, which translated into similar area crop yields.

Because our objective was to produce single-head broccoli, at the densest spacing (10.8 plants $\left./ \mathrm{m}^{2}\right)$, head weights, diameters, and yield are larger than what normally would be harvested at that spacing. Even so, average head diameter was $\leq 15 \mathrm{~cm}$ at the closest spacing and was categorized primarily as 2- to 3stalk bunching broccoli. Because obtaining high-density broccoli stands by direct seeding has not been consistently achieved in Virginia and other southeastern states, transplanting may be the most successful technique to achieve a desired plant stand. However, the costs associated with producing and setting 108,000 plants/ha for bunching broccoli production probably would be prohibitive.

Decreasing plant density had no effect on the harvest index in 1990; however, in 1991, the harvest index was lowest at the two population extremes studied (10.8 and 3.6 plants/

Table 1. Plant density effects on total, single-head, and floret marketable yield.

\begin{tabular}{|c|c|c|c|c|c|c|}
\hline \multirow{3}{*}{$\begin{array}{l}\text { Density } \\
\left(\text { plants } / \mathrm{m}^{2}\right)\end{array}$} & \multirow{3}{*}{$\begin{array}{l}\text { Within-row } \\
\text { spacing } \\
(\mathrm{cm})\end{array}$} & \multicolumn{5}{|c|}{ Marketable yield } \\
\hline & & \multicolumn{2}{|c|}{ Total } & \multicolumn{2}{|c|}{ Single-head } & \multirow{2}{*}{$\begin{array}{l}\text { Florets } \\
\left(\mathrm{t} \cdot h \mathrm{a}^{-1}\right) \\
\end{array}$} \\
\hline & & $\mathrm{t} \cdot \mathrm{ha}^{-1}$ & $\%^{2}$ & $\mathrm{t} \cdot \mathrm{ha}^{-1}$ & $\%$ & \\
\hline \multicolumn{7}{|c|}{1990} \\
\hline 10.8 & 15 & 22.7 & 87 & 0.7 & 3 & 12.6 \\
\hline 5.4 & 30 & 20.5 & 97 & 9.0 & 43 & 12.2 \\
\hline 4.3 & 38 & 18.5 & 91 & 11.0 & 58 & 11.3 \\
\hline 3.6 & 46 & 17.7 & 89 & 11.0 & 70 & 10.9 \\
\hline Linear & & $*$ & NS & $* *$ & $* *$ & NS \\
\hline \multicolumn{7}{|c|}{1991} \\
\hline 10.8 & 15 & 19.4 & 92 & 0 & 0 & 10.7 \\
\hline 7.2 & 23 & 18.7 & 100 & 0.5 & 3 & 10.4 \\
\hline 5.4 & 30 & 18.8 & 100 & 4.9 & 25 & 10.8 \\
\hline 4.3 & 38 & 16.8 & 100 & 7.9 & 46 & 10.0 \\
\hline 3.6 & 46 & 17.0 & 97 & 12 & 71 & 10.8 \\
\hline Linear & & NS & NS & $* * *$ & $* * *$ & NS \\
\hline
\end{tabular}

${ }^{2}$ Percentage data are angular-transformed.

NS, ${ }^{*}, * * * * *$ Nonsignificant or significant at $P \leq 0.05,0.01$, or 0.001 , respectively.

Table 2. Harvest variables of broccoli as influenced by plant density (within-row spacing). ${ }^{\mathrm{z}}$

\begin{tabular}{|c|c|c|c|c|c|}
\hline $\begin{array}{l}\text { Density } \\
\left(\text { plants } / \mathrm{m}^{2}\right)\end{array}$ & $\begin{array}{c}\text { Within-row } \\
\text { spacing }(\mathrm{cm})\end{array}$ & $\begin{array}{c}\mathrm{Ht} \\
(\mathrm{cm})\end{array}$ & $\begin{array}{c}\text { Head } \\
\text { diam }(\mathrm{cm})\end{array}$ & $\begin{array}{l}\text { Plant } \\
\text { wt }(\mathrm{g})\end{array}$ & $\begin{array}{l}\text { Head } \\
\text { wt }(\mathrm{g})\end{array}$ \\
\hline \multicolumn{6}{|c|}{1990} \\
\hline 10.8 & 15 & 51 & 15 & 400 & 241 \\
\hline 5.4 & 30 & 50 & 19 & 676 & 404 \\
\hline 4.3 & 38 & 51 & 20 & 774 & 488 \\
\hline 3.6 & 46 & 51 & 21 & 964 & 560 \\
\hline Linear & & NS & $* * *$ & $* * *$ & $* * *$ \\
\hline \multicolumn{6}{|c|}{1991} \\
\hline 10.8 & 15 & 46 & 14 & 444 & 197 \\
\hline 7.2 & 23 & 44 & 15 & 535 & 523 \\
\hline 5.4 & 30 & 43 & 18 & 656 & 328 \\
\hline 4.3 & 38 & 42 & 19 & 783 & 391 \\
\hline 3.6 & 46 & 42 & 20 & 966 & 490 \\
\hline Linear & & $* *$ & $* * *$ & $* * *$ & $* * *$ \\
\hline
\end{tabular}

${ }^{\mathrm{z}}$ For all variables measured, there were neither significant effects of spatial arrangement nor a spatial arrangement $\times$ within-row spacing interaction; the data reported are means of both spatial arrangements at each plant density.

Ns, **,***N Nonsignificant or significant at $P \leq 0.01$ and 0.001 , respectively. 
$\mathrm{m}^{2}$ ) (Table 3). Allowing the broccoli plants at 46 - $\mathrm{cm}$ WRS to mature to $\geq 20 \mathrm{~cm}$ head diameter did not result in a longer time interval for reaching 50\% harvest, compared with the densest plant spacing (Table 3).

Floret yields. Single-head broccoli by definition yields a greater quantity of florets per unit weight than bunching broccoli. Random field sampling of Virginia-grown, single-head and bunching broccoli revealed that when only the florets were weighed, single-head broccoli was $65 \%$ florets (by weight) and bunching broccoli averaged $45 \%$ florets by weight. In 1991, the optimal spacing for producing singlehead broccoli (46-cm WRS ) produced floret yields as high as those obtained with the densest spacing used for bunching broccoli production (Table 1). The single-heads contain more florets per equivalent unit weight than bunching broccoli. Because more of what consumers desire is being provided, it is possible

Table 3. Harvest index and time (days) to harvest $50 \%$ of the broccoli plants.

\begin{tabular}{|c|c|c|c|}
\hline $\begin{array}{l}\text { Density } \\
\left(\text { plants } / \mathrm{m}^{2}\right)\end{array}$ & $\begin{array}{l}\text { Within-row } \\
\text { spacing } \\
(\mathrm{cm})\end{array}$ & $\begin{array}{l}\text { Harvest } \\
\text { index } \\
(\%)^{2, y} \\
\end{array}$ & $\begin{array}{c}\text { Days to } \\
50 \% \\
\text { harvest }^{\mathrm{x}}\end{array}$ \\
\hline \multicolumn{4}{|c|}{1990} \\
\hline 10.8 & 15 & 38.0 & 65 \\
\hline 5.4 & 30 & 37.0 & 64 \\
\hline 4.3 & 38 & 39.0 & 66 \\
\hline 3.6 & 46 & 37.0 & 65 \\
\hline $\operatorname{LSD}_{(0.05)}$ & & NS & NS \\
\hline \multicolumn{4}{|c|}{1991} \\
\hline 10.8 & 15 & 31.0 & 72 \\
\hline 7.2 & 23 & 33.0 & 73 \\
\hline 5.4 & 30 & 35.0 & 69 \\
\hline 4.3 & 38 & 34.0 & 76 \\
\hline 3.6 & 46 & 31.0 & 73 \\
\hline $\operatorname{LSD}_{(0.05)}$ & & 1.0 & 4 \\
\hline
\end{tabular}

${ }^{2}$ Percentage data are angular-transformed. y Harvest index: [(total marketable head yield)/(total marketable head yield + waste) $] 100$.

${ }^{x}$ Days from transplanting. that single-head broccoli could command a higher price per unit than standard bunching broccoli. Single-head broccoli also seems to offer distinct labor-saving advantages over bunching when broccoli is sold as packaged florets. With single-head broccoli, obtaining equal or even higher floret yields from fewer plants $(36,000$ plants/ha) probably would result in reduced harvest and floret-packaging labor costs, compared to the high-density $(108,000$ plants/ha) plant population needed for bunching broccoli. As broccoli production expands as an alternative crop in the southeastern United States to match the increase in fresh-market consumption, growers can consider producing single-head broccoli. The low plant density optimum (46-cm WRS) for high yields of single-head broccoli offers the grower stand reliability and potential economic advantages over using transplants to achieve the desired, uniformly spaced, plant density.

\section{Literature Cited}

Borcher, E.A. 1979. Broccoli production in Virginia. Vegetable Growers News 7:15.

Canaday, C.H. 1992. Effects of nitrogen fertilization on bacterial soft rot in two broccoli cultivars, one resistant and one susceptible to the disease. Plant Dis. 76:989-991.

Chung, B. 1982. Effects of plant density on the maturity and once-over harvest yields of broccoli. J. Hort. Sci. 57:365-372.

Coon, J. 1991. Broccoli boom creates demand for new types. Amer. Veg. Grower 36(9):44-46.

Cutcliffe, J.A. 1971. Effects of plant population nitrogen, and harvest date on yield and maturity of single-harvested broccoli. HortScience 6:482483.

Cutcliffe, J.A. 1975. Effects of plant spacing on single-harvest yields of several broccoli cultivars. HortScience 10:417-419.

Elson, M.K., R.D. Morse, D.D. Wolf, and D.H. Vaughn. 1992. High temperature inhibition of seed germination and seedling emergence of broccoli. HortTechnology 2:417-419.

Hamm, S.R. 1988. Vegetables and specialties situation and outlook report. U.S. Dept. Agr. Econ. Res. Serv. TVS-245.

Hamm, S.R. 1992. The U.S. supply of vegetables, p. 3-19. In: R.A. Lopez and L. Polopolus (eds.). Vegetable markets in the western hemisphere. Iowa State Univ. Press, Ames.

Jett, L.W. and G.E. Welbaum. 1992. Osmotic and solid phase priming of broccoli seed, p. 73-81. Proc. Natl. Symp. on Stand Establishment for Hort. Crops, Fort Myers, Fla., 16-20 Nov. 1992.

Karst, T. 1990. Vegetable consumption on rise. Packer January:3A.

Karst, T. 1993. Value-added produce creeping up on bulk commodity sales. Packer December:1B.

Klassen, P. 1993. In the green with broccoli. Amer. Veg. Grower 41:10-11.

Kowalenko, C.G. and J.W. Hall. 1987. Nitrogen recovery in single- and multiple-harvested direct-seeded broccoli trials. J. Amer. Soc. Hort. Sci. 112:4-8.

O’Dell, C.R. 1990. Improving broccoli stands. Amer. Veg. Grower 38:25-27.

O’Dell, C.R., R.D. Morse, and P. Ramsey. 1993. Field seeded fall bunching broccoli production: A guide for Virginia farmers. Virginia Coop. Ext. Serv. Publ. 438-011.

Palevitch, D. 1970. Effects of plant population and pattern on yield of broccoli in single harvest. HortScience 5:230-231.

Relf, P.D., C.R. O'Dell, and M.M. Kushad. 1990. Virginia master gardeners reveal preferences in broccoli survey. HortScience 25:706.

Sterrett, S.B., J.W. Mapp, and C.W. Coale. 1990. Feasibility of broccoli as a new enterprise-A systems approach. HortScience 25:638-641.

U.S. Department of Agriculture. 1943. United States standards for broccoli. U.S. Dept. of Agr., Agr. Mktg. Serv., Washington, D.C.

Westcott, M.P. and N.W. Callan. 1990. Modeling plant population and rectangularity effects on broccoli head weights and yield. J. Amer. Soc. Hort. Sci. 115:893-897.

Zink, F.W. and D.A. Akana. 1951. The effect of spacing on the growth of sprouting broccoli. Proc. Amer. Soc. Hort. Sci. 58:160-164. 